\title{
The Role of Ionizing Radiation in Cellular Signaling Pathways, Mutagenesis, and Carcinogenesis
}

\author{
Sakine Rezaie Keihkhaie ${ }^{1 *}$, Khadije Rezaie Keikhaie ${ }^{2}$ \\ ${ }^{1}$ Department of Physics, University of Zabol, Zabol, Iran \\ ${ }^{2}$ Department of Obstetrics and Gynecology, Faculty of Medicine, Pre-neonatology Fellowship, Zabol University of Medical \\ Sciences, Zabol, Iran
}

\section{*Correspondence to}

Sakine Rezaie Keihkhaie, Department of Physics, University of Zabol, Zabol, Iran.

Email: sakinerezaei4@gmail.com

Received November 5, 2018 Accepted December 20, 2018 Published online December 31, 2018

\begin{abstract}
One of the negative effects of ionizing radiation is the alteration of cellular signaling pathways which lead to carcinogenesis and tumorigenesis. In this review, we discussed the impacts of ionizing radiation on cells and cellular signaling pathways. In this regard, exposure to radiation can directly or indirectly alter cellular signaling pathways. Remarkably, irradiated cells release special mediators into cellular matrix, aberrating cell-cell and cell-environment interactions. Most notably, these mediators include nitric oxide (NO), reactive oxygen species (ROS), and cell growth factors which contribute to cellular interactions between irradiated cells and their neighbor cells, a phenomenon known as radiation-induced bystander effect. DNA molecule is the most important cellular compartment damaged by ionizing radiation. On the other hand, the ability of irradiated cells to repair the damaged DNA is very low. Therefore, DNA alternations are passed to the next generations, and ultimately lead to carcinogenesis. The study of ionizing radiations and their impacts on biological systems is of remarkable importance to divulge their impacts on cellular signaling pathways.

Keywords: Physics, lonizing radiation, Cellular signaling pathways, Tumorigenesis, Carcinogenesis
\end{abstract}

Please cite this article as follows: Rezaie Keihkhaie S, Rezaie Keikhaie K. The role of ionizing radiation in cellular signaling pathways, mutagenesis, and carcinogenesis. Int J Basic Sci Med. 2018;3(4):147153. doi:10.15171/ ijbms.2018.26.
Ionizing Radiation and Cancer Development Ionizing radiation is one of the most important factors contributing to carcinogenesis and tumor development. This is mainly promoted by inducing DNA mutations and altering cellular signaling pathways. ${ }^{1}$ Ionizing radiation harbors enough energy to stimulate electron orbits surrounding biological molecules. ${ }^{2,3}$ The ionizing beams are divided into two groups of particles and electromagnetic beams. Conspicuously, the most important particle beams are alpha, beta, electrons, and neutrons, as well as electromagnetic beams which include $\mathrm{X}$ and gamma rays.

Ionizing radiation has been used in a wide range of sciences including medicine. Since the discovery of X-ray by Roentgen in 1895, ionizing radiations have been utilized for diagnostic and therapeutic purposes in medicine with the advent of radiotherapy in 1898 and then throughout the twentieth century. ${ }^{4,5}$ Today, these beams are commonly used in medical imaging devices such as CT scans, image enhancers, and also in radiation therapy devices such as cobalt devices and high-energy $\mathrm{X}$-ray accelerators. They have also been employed in food industry to sterilize foods and kill bacteria and other microorganisms. ${ }^{6-8}$

Nowadays, most people are daily exposed to various sorts of radiations and this can enhance the prevalence of cancers if this phenomenon is not managed and controlled safely. In the carcinogenesis process caused by ionizing radiation, genetic and epigenetic alterations play important and central roles. Accordingly, both endogenous and exogenous agents can modify the impacts of radiationinduced genetic and epigenetic changes and carcinogenesis (Figure 1).

Direct and Indirect Impacts of Radiation Despite extensive research in radiobiology, the identity of the most critical and

(C) 2018 The Author(s); Published by Zabol University of Medical Sciences. This is an open-access article distributed under the terms of the Creative Commons Attribution License (http://creativecommons.org/licenses/by/4.0), which permits unrestricted use, distribution, and reproduction in any medium, provided the original work is properly cited. 


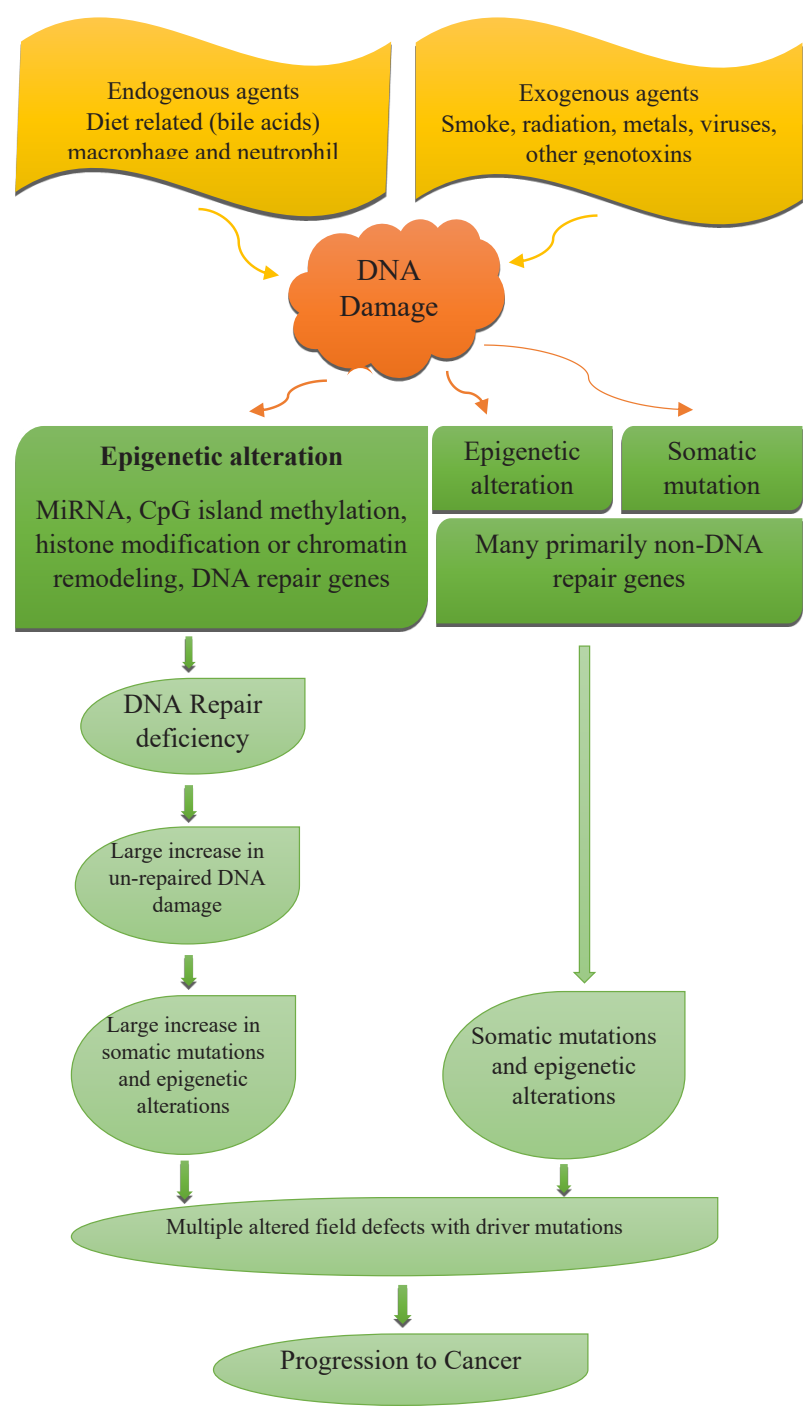

Figure 1. The Effect of Endogenous (Molecular Events) and Exogenous (Environmental Factors) on Different Genetic and Epigenetic Factors Participating in Cancer Development.

radiation sensitive cellular structures has been remained unknown. Damage to these structures is indispensable for promoting radiation-induced cellular death. ${ }^{9}$ It has now been largely agreed that DNA represents the most critical target. However, the impacts of radiation on membrane lipids and proteins should not be disregarded. ${ }^{11,12}$

When radiation is absorbed into biological materials, it may directly collide with critical cellular targets and excite their atoms and electrons. The recent event itself can trigger a chain of reactions that lead to biological alternations. This phenomenon is called the direct action of radiation. ${ }^{13,14}$ Alternately, the beams may collide with atoms or other molecules (especially water) and produce free radicals that can penetrate the cell and damage the sensitive target molecules. This phenomenon is called indirect action of radiation. ${ }^{15}$

Free radicals are mediators not coupled with an electron orbit. An electron orbital not only spins around the nucleus but also around its own axis. ${ }^{16}$ This electron circulation may be either clockwise or counterclockwise. In one atom with a pair of electrons, the electron spins are in parallel with one electron spinning clockwise and the other in the opposite direction. Regardless of whether the atom or molecule is electrically neutral or ionized, this chemical mode produces a lot of chemical stability. ${ }^{17}$

\section{The Effects of Radiation on DNA}

Ionizing radiation may release much of their energy near the DNA molecule and cause serious damages to either single or double strands of DNA. ${ }^{18}$ If a cluster of these events occurs within a $2 \mathrm{~nm}$ diameter of helical DNA, it is likely that both DNA strands will be broken. ${ }^{19}$ In the case of low-level beams, a linear and dose-dependent fracture response has been noted to double-stranded DNA. ${ }^{20}$ The fracture of double-stranded DNA leading to DNA dissociation is warranted in particular when the fracture is larger than 5 nucleotides long. However, the doublestranded DNA damages occur in the ratio of 1: 50 in the favor of single-strand defects. ${ }^{21}$

Whether the DNA damage is double- or single-stranded, cells are able to repair both types of damages over a short period of several hours (Table 1). In the case of singlestranded DNA injuries, one of the 2 DNA strands serves as a transcription template which lowers the rate of error, rendering this type of repair error-free. ${ }^{25} \mathrm{On}$ the other hand, in the case of double-stranded DNA fractures, a number of nucleotides may be incompletely removed from each of the two DNA strands, so that only a part of the two-stranded defects caused by ionizing radiation is fully and correctly repaired. Accordingly, these unfixed alternations may ultimately lead to sustained cellular damages, DNA mutations, carcinogenesis, and tumor development. ${ }^{22-24}$

\section{Radiation-Induced Bystander Effect}

High dose radiations can expose excess energy to human body, thereby inflicting destructive effects on the living tissues. ${ }^{26}$ Since the discovery of radiation, the biological effects of radiation has extensively been studied regarding the effects of different doses, dose rates, and types of radiations..$^{27,28}$ These data are largely derived from medical experiments and instruments such as radiation therapy, radiation accelerating devices such as cyclotron, radiation accidents from the nuclear power industries and nuclear weapons, ${ }^{29,30}$ and finally from experiments conducted on animals. $^{31}$

A recently-suggested phenomenon participating in adaptive responses to radiation is the bystander effect in which radiated cells alter the biology of their surrounding environment. The radiation effects observed in neighboring cells include cell death, chromosomal defects, genetic and gene expression changes, cell cycle delay, genomic instability, and neoplastic transformation. The mechanisms underlying the impacts on neighboring 
Table 1. DNA Lesions and Respective Repair Pathways

\begin{tabular}{|c|c|c|}
\hline Type of DNA Lesions & Source & DNA Damage Repair Pathway \\
\hline $\begin{array}{l}\text { Base mismatches, incorrect } \\
\text { insertion and deletion of } \\
\text { nucleotides }\end{array}$ & Replication errors & MMR \\
\hline DNA ICLs & $\begin{array}{l}\text { Replication events and chemotherapeutic } \\
\text { drugs like mitomycin C }\end{array}$ & NER, FA pathway \\
\hline $\begin{array}{l}\text { Bulky and helix-distorting } \\
\text { DNA adducts }\end{array}$ & $\begin{array}{l}\text { UV rays and chemical mutagens like } \\
\text { cisplatin }\end{array}$ & NER, FA pathway \\
\hline SSBs & $\begin{array}{l}\text { lonizing radiation and reactive oxygen } \\
\text { species }\end{array}$ & Single-strand break repair \\
\hline DSBs & $\begin{array}{l}\text { lonizing radiation, reactive oxygen } \\
\text { species, and replication stress }\end{array}$ & $\begin{array}{l}\text { DSBs are repaired either by NHEJ or by HRR in a cell } \\
\text { cycle specific manner. Some overlap exists between } \\
\text { HRR and NHEJ pathways. DSBs which are not } \\
\text { processed by NHEJ can be processed by HRR during S } \\
\text { and G2 phases. }\end{array}$ \\
\hline $\begin{array}{l}\text { Damaged bases and non-helix- } \\
\text { distorting DNA lesions }\end{array}$ & $\begin{array}{l}\text { lonizing radiation and reactive oxygen } \\
\text { species }\end{array}$ & $\begin{array}{l}\text { BER. In case of impaired BER, the SSBs are converted } \\
\text { to DSBs, which are repaired by HRR during S and G2 } \\
\text { phases. This synthetic lethal relationship is exploited by } \\
\text { the use of PARP inhibitors to kill HRR deficient tumors. }\end{array}$ \\
\hline
\end{tabular}

Abbreviations: MMR; mismatch repair, ICL; Interstrand cross-links, NER; Nucleotide excision repair, FA; Fanconi anaemia, DSBs; Double strand breaks, NHEJ; Non-homologous end joining, HRR; Homologous recombinational repair, SSBs; single strand breaks, PARP; poly ADP ribose polymerase.

cells are obscured. There is a vast amount of literature on this subject, however, no definitive conclusion could yet be reached. ${ }^{32,33}$ Researchers believe that target cells communicate with their neighboring cells by releasing soluble materials or through cellular contacts, thereby causing them to eventually react to these effects. ${ }^{34,35}$

Some evidence suggests that these messenger molecules should be able to cross the gap between cells. Correspondingly, some of these mediators have been found as reactive oxygen species (ROS), nitric oxide (NO), cytokines, and growth factors which contribute to these cellular communications and act as the neighboring messengers. ${ }^{36}$

\section{The Role of NO and ROS}

The NO molecule is made by the conversion of $\mathrm{L}$-arginine to L-citrulline in the presence of NADPH and oxygen. Sphingomyelinase, which is present in the cell membranes, stimulates the production of NO in the cells exposed to ionizing radiation. ${ }^{37,38}$ On the other hand, the TP53 molecule inhibits NO production in irradiated cells. Nevertheless, in the cells containing mutated TP53 gene, the NO molecule can effectively be produced. NO mainly acts through a dose-dependent manner. At high concentrations, $\mathrm{NO}$ and its derivatives (such as ONOO and $\mathrm{N}_{2} \mathrm{O}_{3}$ ) can promote cell death by inducing DNA damage. ${ }^{39,40}$ However, at low concentrations, NO prevents apoptosis ${ }^{41}$ and stimulates cell growth. ${ }^{42}$ ROS, superoxide, hydrogen peroxide, and hydroxyl are produced in the presence of oxygen in the cells exposed to radiation. These mediators can subsequently promote damages to cellular components such as DNA, lipids, and proteins.

Considering the roles of NO and ROS in cell damage, many studies have been conducted to determine their impacts in producing the bystander effect. ${ }^{43,} 44$ Two approaches have been adopted to scrutinize the effects of these mediators in radiation-induced bystander effect. In the first approach, the concentration of NO or ROS is measured in the target and adjacent cells in order to determine whether or not the production of $\mathrm{NO}$ or ROS in surrounding cells is induced by irradiated cells. In the second approach, the NO and ROS inhibitors are employed to evaluate their effects in inducing the bystander effect.

\section{Cytokines and Growth Factors}

Cytokines and growth factors can regulate cell proliferation, differentiation, and death. These molecules play a leading role in preventing neoplastic transformation by provoking an integrated response to complex environmental stimuli. ${ }^{45}$ Likewise, these mediators can contribute as secondary messengers to integrate cellular adaptive responses to ionizing radiation and develop the by stander effect. Studies have shown that transforming growth factor $\beta 1$ (TGF $\beta 1$ ) can promote similar effects against ionizing radiation in cultured cells, highlighting this growth factor as a potent bystander effect mediator (Figure 2). ${ }^{46,47}$

Other studies have also suggested that TGFa, tumor necrosis factor $\alpha(\mathrm{TNF} \alpha), \mathrm{TGF} \beta 1$, and interleukin 8 (IL8 ) can promote the bystander effect. ${ }^{48,49}$ In this regard, another study indicated that there was a relationship between the NO production and TGF $\beta 1$ level, proving an indirect role for NO in induction of bystander effect by triggering TGF $\beta 1$ in irradiated cells. ${ }^{50}$

TGF $\beta 1$ is a relatively stable molecule which can 


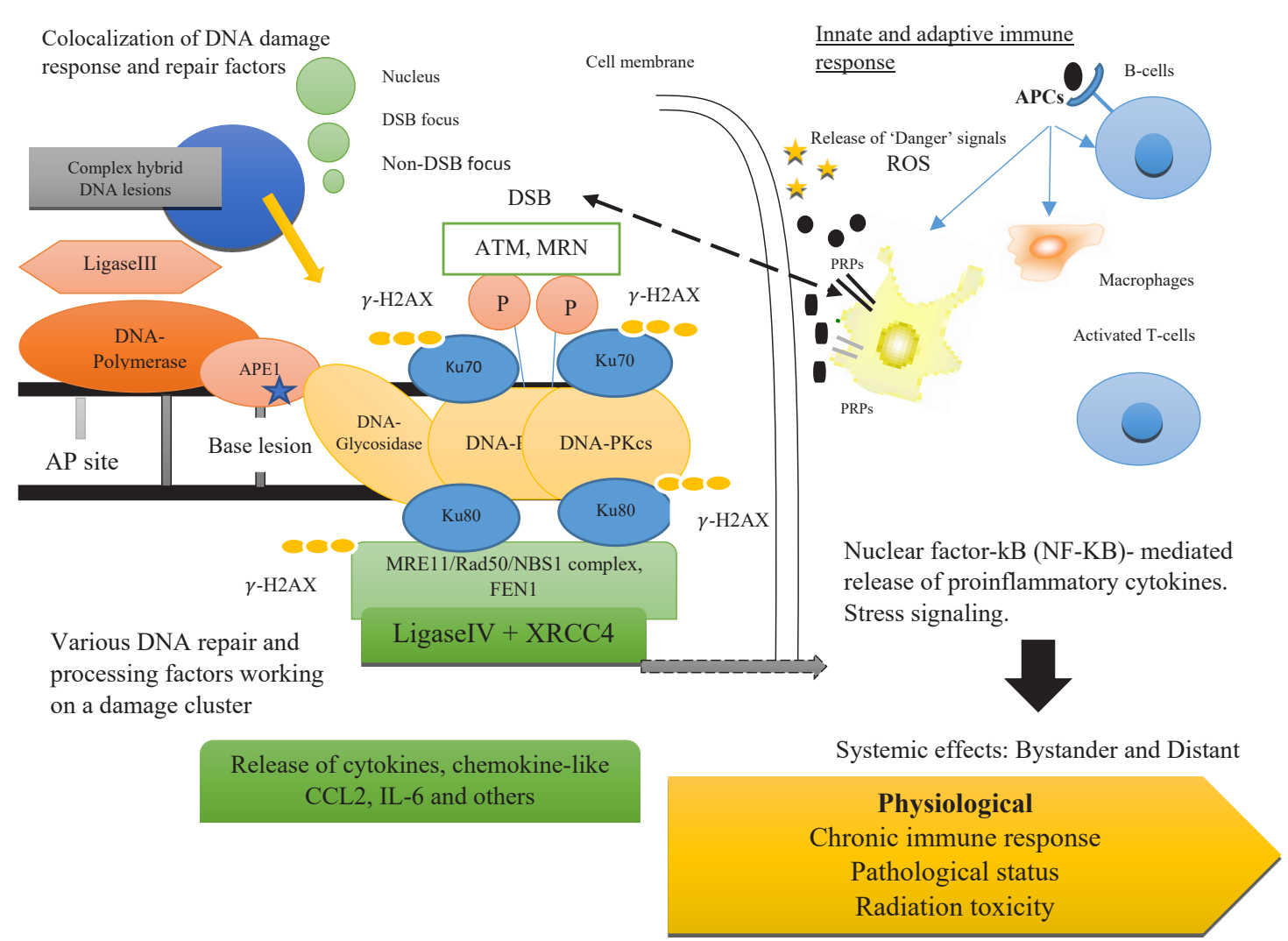

Figure 2. Extracellular Responses by Cytokines and Growth Factors Induce Cell Proliferation, Differentiation, and Death. These mechanisms play a key role in preventing neoplastic transformation by provoking an integrated response to external DNA damage. Abbreviations; AP site; apurinic/apyrimidinic site, XRCC4; X-Ray Repair Cross Complementing 4, MRE11; meiotic recombination 11, ATM; ataxia telangiectasia mutated, FEN1; Flap endonuclease 1, DNA-PKC; DNA-dependent protein kinase, DSB; double-strand break, ROS; reactive oxygen species, APC; antigen presenting cells.

easily penetrate into the intercellular matrix and in this way, reach neighboring cells and alter their biological functions partly by regulating cellular signaling and calcium-dependent pathways.

Radiation-Induced DNA Damage as a Bystander Effect Formation of $\mathrm{H} 2 \mathrm{~A}$ histone family member $\mathrm{X}(\gamma \mathrm{H} 2 \mathrm{AX})$ foci, double-strand break (DSB) in DNA, chromosomal fractures, and cellular death in cells surrounding the irradiated cells indicate DNA molecule as a main target in bystander effect. Nonetheless, the $\gamma \mathrm{H} 2 \mathrm{AX}$ foci may also be formed by the influence of ROS over neighboring cells. ${ }^{51}$ It has been shown that the number of $\gamma \mathrm{H} 2 \mathrm{AX}$ foci has been higher in the cells neighboring to radiation-exposed cells rather than normal cells. ${ }^{52,53}$ This observation indicates the role of bystander effect in the DSB formation in neighboring cells. Increased concentration of DNA-dependent protein kinase (DNA$\mathrm{PKC}$ ) molecules involved in DSB regeneration is another evidence confirming the DSB formation in neighboring cells. ${ }^{54}$ Accordingly, chromosomal fractures have also been reported as a bystander effect in the cells surrounding radiation-exposed cells. Regardless of these, whether bystander effects on DNA and chromosomes are directly induced by radiation or indirectly by some unknown mediators needs to be further investigated..$^{53}$

\section{Radiation, Microenvironment, and Carcinogenesis}

Understanding the bystander effect is further expanded by acknowledging the fact that the ionizing radiation may directly act through collision with the cells or their microenvironment. Scientific findings have shown that ionizing radiation has multicellular and multifactorial effects on cells and the microenvironment. ${ }^{55,56}$ Cellular microenvironment plays an essential role in the interactions of cells with each other and with other extrinsic factors. These interactions can regulate the cellular growth, proliferation, differentiation, and death by augmenting cell-environment interactions.

Extracellular matrix is a main microenvironment which affects irradiated cells. Radiation can trigger release of soluble materials such as proteases, cytokines, growth factors, and chemokines, which subsequently leads to tissue and extracellular matrix stress, thereby affecting cell-microenvironment interactions..$^{57,58}$

Noticeably, adaptive responses to microenvironmental damage can restore the damage, maintain homeostasis, and eventually recover cell-microenvironment 


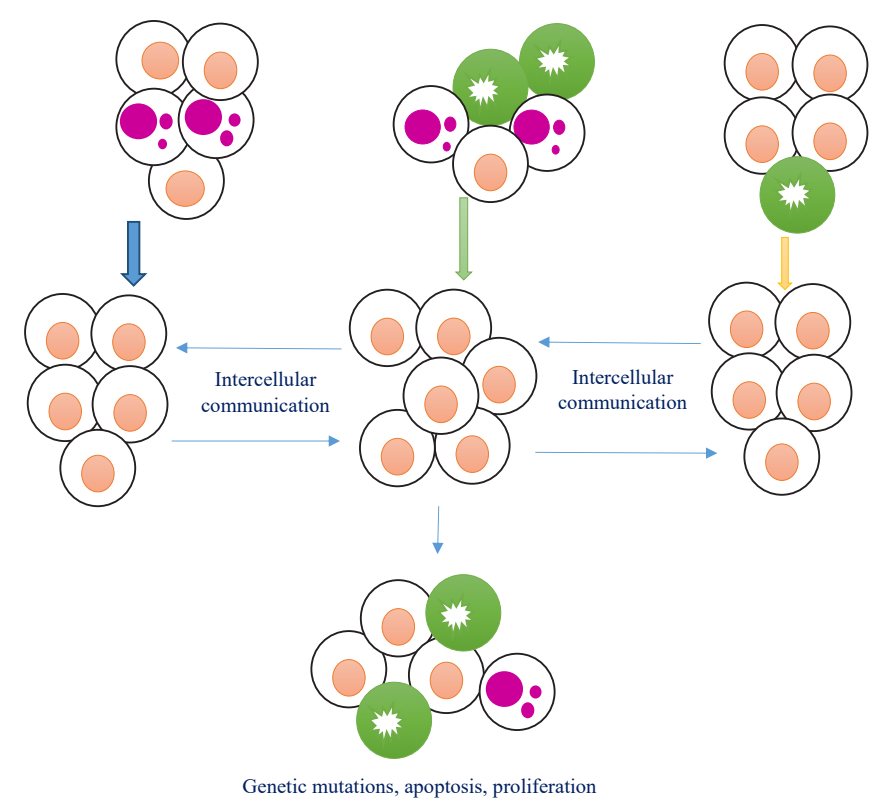

Figure 3. The Impact of Low and High Dose Radiations and Intracellular Communications in Cell Mutation.

interactions. Factors other than ionizing radiation such as ROS, TGF $\beta 1$, and cancerous cells' microenvironment can also affect the microenvironment and produce effects similar to that produced by radiation (Figure 3)..$^{59-63}$

Conclusively, it seems that microenvironmental impairment participates as a main route through which radiation may promote its effects on biological systems. Accordingly, the role of microenvironment alternations has been demonstrated in inducing bone marrow failure in the production of blood cells following acute radiation. ${ }^{64}$ Furthermore, microenvironment of irradiated cells containing molecular messengers (such as ROS, NO, cytokines, growth factors-i.e. TGF $\beta 1$ ) has been reported to reproduce bystander effects in non-irradiated cells.

In particular, TGF $\beta 1$ molecule produced by stromal cells can impart an important role in regulating microenvironmental bystander effects. ${ }^{65-69}$ The role of this molecule in three processes of maintaining tissue stability, responding to radiation, and developing bystander effect further confirms a link between the bystander effect and the microenvironmental response to radiation.

\section{Conclusion}

While high-dose radiation can promote direct damage to cellular components such as DNA, low-dose radiation can alter cellular communications by projecting the bystander effects. The study of radiation effects on genetic and epigenetic alternations in different cancers by suitable molecular techniques is highly recommended. Furthermore, identification of potential mediators exerting the bystander effects can boost our knowledge in radiation-induced adaptive responses.

\section{Conflict of Interests}

The author declares no conflict of interests.

\section{Ethical Issues}

Not applicable.

\section{Financial Support \\ Not applicable.}

\section{Acknowledgements}

The authors appreciate all those who assisted in preparing this manuscript.

\section{References}

1. Pines A, Dijk M, Makowski $\mathrm{M}$, et al. TRiC. controls transcription resumption after UV damage by regulating Cockayne syndrome protein A. Nat Commun. 2018;9(1):1040. doi:10.1038/s41467-018-03484-6

2. Kim C, Yang J, Jeong SH, et al. Yeast-based assays for characterization of the functional effects of single nucleotide polymorphisms in human DNA repair genes. PLoS One. 2018;13(3):e0193823. doi:10.1371/journal.pone.0193823

3. Hu H, Hao L, Tang C, Zhu Y, Jiang Q, Yao J. Activation of KGFR-Akt-mTOR-Nrf2 signaling protects human retinal pigment epithelium cells from Ultra-violet. Biochem Biophys Res Commun. 2018;495(3):2171-2177. doi:10.1016/j.bbrc.2017.12.078

4. Roy S. Impact of UV Radiation on Genome Stability and Human Health. Adv Exp Med Biol. 2017;996:207-219. doi:10.1007/978-3-319-56017-5_17

5. Rossnerova A, Pokorna M, Svecova V, et al. Adaptation of the human population to the environment: Current knowledge, clues from Czech cytogenetic and "omics" biomonitoring studies and possible mechanisms. Mutat Res. 2017;773:188203. doi:10.1016/j.mrrev.2017.07.002

6. Supek F, Lehner B. clustered mutation signatures reveal that error-prone dna repair targets mutations to active genes. Cell. 2017;170(3):534-547.e23. doi:10.1016/j. cell.2017.07.003

7. Zhao WJ, Xu J, Chen XJ, Liu HH, Yao K, Yan YB. Effects of cataract causing mutations W59C and W151C on 
$\beta B 2$-crystallin structure, stability and folding. Int $\mathrm{J}$ Biol Macromol. 2017 Oct;103:764-770. doi:10.1016/j. ijbiomac.2017.05.109

8. Scanlon SE, Scanlon CD, Hegan DC, Sulkowski PL, Glazer PM. Nickel induces transcriptional down-regulation of DNA repair pathways in tumorigenic and non-tumorigenic lung cells. Carcinogenesis. 2017;38(6):627-637. doi:10.1093/ carcin/bgx038

9. Bokstein F, Dubov T, Toledano-Alhadef H, BernsteinMolho R, Constantini S, Evans DG, Ben-Shachar S. Cranial irradiation in childhood mimicking neurofibromatosis type II. Am J Med Genet A. 2017;173(6):1635-1639. doi:10.1002/ ajmg.a.38211

10. Jarrett SG, Carter KM, D'Orazio JA. Paracrine regulation of melanocyte genomic stability: a focus on nucleotide excision repair. Pigment Cell Melanoma Res. 2017;30(3):284-293. Doi:10.1111/pcmr.12582

11. Yang B, Xu QY, Guo CY, et al. MHY1485 ameliorates UV-induced skin cell damages via activating mTORNrf2 signaling. Oncotarget. 2017;8(8):12775-12783. Doi: 10.18632/oncotarget.14299

12. Schubert S, Rieper P, Ohlenbusch A, et al. A unique chromosomal in-frame deletion identified among seven XP-C patients. Photodermatol Photoimmunol Photomed. 2016;32(5-6):276-283. Doi:10.1111/phpp.12251

13. Pacholczyk M, Czernicki J, Ferenc T. The effect of solar ultraviolet radiation (UVR) on induction of skin cancers. Med Pr. 2016;67(2):255-66. doi:10.13075/mp.5893.00342

14. Ou X, Wei B, Zhang Z, et al. Detection of UVA/UVCinduced damage of p53 fragment by rolling circle amplification with AIE gens. Analyst. 2016;141(14):4394-9. Doi:10.1039/c6an00831c

15. Li KR, Yang SQ, Gong YQ, et al. 3H-1,2-dithiole-3-thione protects retinal pigment epithelium cells against Ultraviolet radiation via activation of Akt-mTORC1-dependent Nrf2-HO-1 signaling. Sci Rep. 2016;6:25525. Doi:10.1038/ srep 25525

16. Avila AI, Illing A, Becker F, et al. Xpg limits the expansion of haematopoietic stem and progenitor cells after ionising radiation. Nucleic Acids Res. 2016;44(13):6252-61. Doi: 10.1093/nar/gkw376

17. Aguileta G, Badouin $\mathrm{H}$, Hood ME, et al. Lower prevalence but similar fitness in a parasitic fungus at higher radiation levels near Chernobyl. Mol Ecol. 2016;25(14):3370-83. Doi:10.1111/mec.13675

18. Krüger CT, Fischer BM, Armant O, Morath V, Strähle U, Hartwig A. The in vitro PIG-A gene mutation assay: glycosylphosphatidylinositol (GPI)-related genotypeto-phenotype relationship in TK6 cells. Arch Toxicol. 2016;90(7):1729-36. Doi: 10.1007/s00204-016-1707-x

19. Babu V, Schumacher B. A C. elegans homolog for the UVhypersensitivity syndrome disease gene UVSSA.DNA Repair (Amst). 2016;41:8-15.doi: 10.1016/j.dnarep.2016.03.008

20. Matsumoto H, Hamada N, Takahashi A, Kobayashi Y, Ohnishi T. Vanguards of paradigm shift in radiation biology: Radiation induced adaptive and bystander responses. J Radiat Res. 2007;48(2):97106.doi: 10.1269/jrr.06090

21. Matsumoto H, Takahashi A, Ohnishi T. Radiation-induced adaptive responses and by stander effects. Biol Sci Space. 2004; 18(4): 247254. doi:10.2187/bss.18.247

22. Shao C, Aoki M, Furusawa Y. By stander effect in lymphoma cells vicinal to irradiated neoplastic epithelial cells: nitric oxide is involved. J Radiat Res. 2004;45(1): 97103. doi:10.1269/jrr.45.97

23. Han W, WU L, Chen S, et al. Constitutive nitric oxide acting as a possible intercellular signaling molecule in the initiation of radiation induced DNA double strand breaks in non irradiated by stander. Oncogene 2007;26:23302339. doi:10.1038/sj.onc.1210024

24. Shao C, Folkard M, Michael BD, Prise KM. By stander signaling between glioma cells and fibroblasts targeted with counted particles. Int J Cancer. 2005;116:45-51. doi:10.1002/ijc.21003

25. Lyng FM, Seymour CB, Mothersill C. Initiation of apoptosis in cells exposed to medium from the progency of irradiated cells: A possible mechanism for by stander induced genomic instability? Radiat Res 2002;157:365370.

26. Yang H, Asaad N, Held KD. Medium mediated intercellular communication is involved in By stander responses of Xray irradiated normal human fibroblasts. Oncogene 2005;24:2096-2103. doi: 10.1038/sj.onc.1208439

27. Shao C, Lyng FM, Folkard M, Prise KM. Calcium fluxes modulate the radiation induced By stander responses in targeted glioma and fibroblast cells. Radiat Res. 2006;166(3):479487. doi:10.1667/rr3600.1

28. Yang H, Anzenberg V, Held KD. The time dependence of bystander responses induced by iron-ion in normal human skin fibroblasts. Radiat Res. 2007;168(3):2928. doi:10.1667/ rr0864.1

29. Baskar R, Balajee AS, Geard CR. Effects of low and high LET radiations on bystander human lung fibroblast cell survival. Int J Radiat Biol. 2007;83(8):5519. doi:10.1080/09553000701384499

30. Shao C, Folkard M, Prise KM. Role of TGF $\beta 1$ and nitric oxide in the bystander response of irradiated glioma cells. Oncogene 2008;27(4):434-40. doi:10.1038/sj.onc.1210653

31. Wang R, Coderre JR. A Bystander effect in alpha particle irradiations of human prostate tumor cells. Radiat Res. 2005; 164:711-722.

32. Burdak Rothkamm S, Short SC, Folkard M, Rothkamm K, Prise KM. ATR dependent radiation induced $\gamma \mathrm{H} 2 \mathrm{AX}$ foci in bystander primary human astrocytes and glioma cells. Oncogene. 2007;26: 9931002. doi:10.1038/sj.onc. 1209863

33. Maguire P, Mothersill C, Seymour C, Lyng FM. Medium from irradiated cells induces dose dependent mitochondrial changes and BCL2 responses in unirradiated human keratinocytes. Radiat Res. 2005 ;163(4):38490.

34. Hu B, WU L, Han W, et al. The time and spatial effects of by stander response in mammalian cells induced by low dose radiation. Carcinogenesis. 2006;27(2): 245251. doi:10.1093/ carcin/bgi224

35. Konopacka M, Rzeszowska Wolny J. The bystander effect induced formation of micro nucleated cells is inhibited by antioxidants, but parallel induction of apoptosis and loss of viability are not affected. Mutat Res. 2006;593:3238. doi:10.1016/j.mrfmmm.2005.06.017

36. Mothersill C, Seymour C. Radiation induced bystander effects: past history and future directions. Radiat Res. 2001; 155:759767.

37. Chaudhry MA. Bystander effect: Biological endpoints and microarray analysis. Mutat Res. 2006;597:98-112. doi:10.1016/j.mrfmmm.2005.04.023

38. Hamada N, Matsumoto $\mathrm{H}$, Hara $\mathrm{T}$, Kobayashi $\mathrm{Y}$. Intercellular and intracellular signaling pathways mediating ionizing radiation induced bystander effects. J Radiat Res. 2007;48(2):8795. doi:10.1269/jrr.06084 
39. Facotti A, Ballarini F, Cherubini R, et al. Gamma ray induced by stander effect in tumour glioblastoma cells: a specific study on cell survival, cytokine release and cytokine receptors. Radiat Prot Dosimetry. 2006;122(1-4):271-4. doi:10.1093/rpd/ncl431

40. Zhou H, Ivanov VN, Gillespie J, et al. Mechanism of Radiation induced by stander effect: Role of the cyclooxigenase2 signaling pathway. Proc Natl Acad Sci 2005;102(41): 1464114646. doi:10.1073/pnas.0505473102

41. Hei TK. Cyclooxygenase 2 as a signaling molecule in radiation induced by stander effect. Mol Carcinog. 2006;45:455-460. doi:10.1002/mc.20219

42. Zhou H, Ivanov VN, Gillespie J, et al. Mechanism of radiation induced by stander effect: Role of the cyclooxygenase2 signaling pathway. Proc Natl Acad Sci U S A. 2005;102(41):14641-14646. doi:10.1073/ pnas.0505473102.

43. Suzuki M, Tsuruoka C. Heavy charged particle produce a bystander effect via cell -cell junctions. Biol Sci Space. 2004;18(4):241246. doi:10.2187/bss.18.241

44. Sokolov MV, Smilenov LB, Hall EJ, Panyutin IG, Bonner WM, Sedelnikova OA. Ionizing radiation induces DNA double strand breaks in bystander primary human fibroblasts. Oncogene 2005;24:7257-7265. doi:10.1038/ sj.onc. 1208886

45. Banaz Yasar F, Lennartz K, Winterhager E, Gellhaus A. Radiation induced by stander effects in malignant trophoblast cells are independent from gap junctional communication. J Cell Biochem. 2008;103:149-161. doi:10.1002/jcb.21395

46. Mitchell SA, Randers Pehrson G, Brenner DJ, Hall EJ. The Bystander Response in $\mathrm{C} 3 \mathrm{H} 10 \mathrm{~T}^{1} \frac{1}{2}$ Cells: The influence of cell -to-cell contact. Radiat Res. 2004;61:397-401. doi: $10.1667 / \mathrm{rr} 3137$

47. Suzuki M, Zhou H, Geard CR, Hei TK. Effect of medium on chromatin damage in bystander mammalian cells. Radiat Res. 2004;162(3):2649.

48. Kashino G, Prise KM, Suzuki K, Matsuda N, Kodama S, Suzuki M, et al. Effective suppression of bystander effects by DMSO treatment of irradiated CHO cells. J Radiat Res. 2007;48:327333. doi:10.1269/jrr.07008

49. Mitchell SA, Marino SA, Brenner DJ, Hall EJ. Bystander effect and adaptive responses in $\mathrm{C} 3 \mathrm{H} 10 \mathrm{~T} 1 / 2$ cells. Int J Radiat Biol. 2004 ;80(7):465472.

50. Boyd M, Ross SC, Dorrens J, et al. Radiation induced biologic bystander effect elicited in vitro by targeted radiopharmaceuticals labeled with $\alpha, \beta, \gamma$ and auger electron emitting radionuclides. J Nucl Med. 2006;47(6):10071015.

51. Mothersill C, Seymour CB, Joiner MC. Relationship between radiation induced low dose hypersensitivity and the bystander effect. Radiat Res. 2002;157:526532.

52. Han W, Wu L, Hu B, et al. The early and initiation processes of radiation induced bystander effects involved in the induction of DNA double strand breaks in Non irradiated cultures. Br J Radiol. 2007;80:S7S12. doi:10.1259/ bjr/44550200

53. Mothersill C, Seymour C. Medium from irradiated human epithelial cells but not human fibroblasts reduces the clonogenic survival of unirradiated cells. Int J Radiat Biol. 1997;71(4):421427.

54. Balajee AS, Ponnaiya B, Baskar R, Geard CR. Induction of replication protein $\mathrm{A}$ in bystander cells. Radiat Res.
2004;162:677686.

55. Kashino G, Prise KM, Schettino G, et al. Evidence for induction of DNA double strand breaks in the bystander response to targeted soft Xrays in $\mathrm{CHO}$ cells. Mutat Res. 2004;556:209-215. doi:10.1016/j.mrfmmm.2004.08.009

56. Prise KM, Burdak Rothkamm S, Folkard M, Kashino G, Shao C, Tartier L. New insights on radiation induced by stander signalling and its relationship to DNA repair. Int Conger Ser. 1299 2007;121-127. doi:10.1016/j.ics.2006.10.018

57. Shao C, Folkard M, Michael BD, Prise KM. Targeted cytoplasmic irradiation induces bystander responses. Proc Natl Acad Sci U S A. 2004;101(37):13495-13500. doi:10.1073/pnas.0404930101

58. Kashino G, Suzuki K, Matsuda N, et al. Radiation induced by stander signals are independent of DNA damage and DNA repair capacity of the irradiated cells. Mutat Res. 2007;619:134. doi:10.1016/j.mrfmmm.2007.02.005

59. Kanasugi Y, Hamada N, Wada S, Funayama T, Sakashita T, Kakizaki T, et al. Role of DNA-PKcs in the bystander effect after low or high-LET radiation. Int J Radiat Biol. 2007;83(2): 7380 .

60. Mothersill C, Seymour C. Radiation induced bystander effects: are they good, bad or both? Med Confl Surviv 2005;21(2):101-110.

61. Grosovsky AJ. Radiation induced mutations in unirradiated DNA. Proc Natl Acad Sci. 1999;96:53465347.

62. Nugent SM, Mothersill CE, Seymour C, et al. Increased mitochondrial mass in cells with functionally compromised mitochondria after exposure to both direct $\gamma$ radiation and bystander factors. Radiat Res 2007;168(1):134142. doi: $10.1667 / \mathrm{rr} 0769.1$

63. Barcellos Hoff MH, Park C, Wright EG. Radiation and the microenvironment tumorigenesis and therapy. Nat Rev Cancer. 2005;5(11):867875. doi:10.1038/nrc1735

64. Sokolov MV, Dickey JS, Bonner WM, Sedelnikova OA. Gamma H2AX in bystander cells: not just a radiationtriggered event, a cellular response to stress mediated by intercellular communication. Cell Cycle. 2007;6(18):22102. doi:10.4161/cc.6.18.4682

65. Mothersill C, Seymour C. Radiation induced bystander and other non targeted effects: Novel intervention points in cancer therapy? Curr Cancer Drug Targets. 2006;6(5): 44754. doi:10.2174/156800906777723976

66. Fattahi S, Nikbakhsh N, Taheri H, et al. Prevalence of multiple infections and the risk of gastric adenocarcinoma development at earlier age. Diagn Microbiol Infect Dis. 2018;92(1):62-68. doi: 10.1016/j.diagmicrobio.2018.04.015.

67. Samadani AA, Nikbakhsh N, Pilehchian M, Fattahi S, Akhavan-Niaki H. Epigenetic changes of CDX2 in gastric adenocarcinoma. J Cell Commun Signal. 2016;10(4):26772.doi:10.1007/s12079-016-0327-9

68. Norollahi SE, Alipour M, Rashidy-Pour A, Samadani AA, Vahedi Larijani L. regulatory fluctuation of wnt16 gene expression is associated with human gastric adenocarcinoma, Journal of gastrointestinal cancer. J Gastrointest Cancer. 2017. doi: 10.1007/s12029-017-0022-y.

69. Pilehchian Langroudi M, Nikbakhsh N, Samadani AA, et al. FAT4 hypermethylation and grade dependent downregulation in gastric adenocarcinoma. J Cell Commun Signal. 2017;11(1):69-75. doi:10.1007/s12079-016-0355-5 